\title{
Leadership Role Models in Fairy Tales - Using the Example of Folk Art and Fairy Tales, and Novels Especially in Cross-Cultural Comparison: German, Russian and Romanian Fairy Tales
}

\author{
Maria Bostenaru Dan ${ }^{1,2} \&$ Michael Kauffmann ${ }^{3}$ \\ ${ }^{1}$ Urban and Landscape Design Department, "Ion Mincu” University of Architecture and Urbanism, Bucharest, \\ Romania \\ ${ }^{2}$ Marie Curie Fellows Association, Brussels, Belgium \\ ${ }^{3}$ Formerly Graduate Research Network “Natural Disasters”, University of Karlsruhe, Karlsruhe, Germany \\ Correspondence: Maria Bostenaru Dan, Urban and Landscape Design Department, "Ion Mincu" University of \\ Architecture and Urbanism, Bucharest 010014, Romania. Tel: 40-21-3077-180. E-mail: maria.bostenaru@iaim.ro
}

Received: August 11, 2013 Accepted: September 20, 2013 Online Published: October 11, 2013

doi:10.5539/res.v5n5p59 URL: http://dx.doi.org/10.5539/res.v5n5p59

\begin{abstract}
In search of role models for leadership, this article deals with leadership figures in fairy tales. The focus is on leadership and female domination pictures. Just as the role of kings and princes, the role of their female hero is defined. There are strong and weak women, but by a special interest in the contribution is the development of the last of the first to power versus strength. Leadership means to deal with one's own person, 'self-rule, then, of rulers'. In fairy tales, we find different styles of leadership and management tools. As properties of the good boss is praised in particular the decision-making and less the organizational skills.
\end{abstract}

Keywords: personnel management, project management, mission statement, fairy tales, women cross-culturally, leading figure, king, queen, decision

\section{What Are Fairy Tales?}

Michael Ende, for whom the division of literature into "one for adults and another for children" was "serious symptom", has called his book "Momo" a "fairy tale novel", a term that applies also to "The Neverending Story". This tale belongs to the novel literary pieces that have equal importance for all ages, such as "Arthurian legends, biblical stories, [...] Gulliver's Travels, Don Quixote or the so-called folk tales." In this work, not all of these types are analyzed. The emphasis is on folk tales, but also literary fairy tales, legends, fairy tales and novels, the so-called fantasy genre were included.

\subsection{Characteristics of Fairy Tales}

A fairy tale is a narrative, with imaginary and real characters acting within fantastic and real events. There are no limits between fantastic and real. The real characters are not only humans but also other creatures with which they interact. The characters, men and women, don't have a distinguished interior and exterior, and are usually featured in black and white, either good or evil. That "good wins" is a rule of fairy tales. The plot is not placed in space and time and the story also has so no ties to identifiable persons.

In general, the hero or heroine is on an ascending scale. Usually this scale is composed of three elements, showing the preference for symbolic.

\subsection{Structure of Fairy Tales}

There are numerous structures of fairly tales but something is in common to all. The evil disrupts the lives of mankind. The hero / heroine has the mission to restore the order. In this mission (s)he is helped by several fantastic characters, but also the own ingenuity. In the end, the good triumphs. The family of a hero is also having mostly the same, schematic structure. Brothers or sisters (usually 3) are rivals and it goes out of the conflict.

\section{Leadership Figures in Fairy Tales}

Thoughts about power structures in fairy tales lead to the first issue which means that reign means to have 
absolute control. But this is a symbol. A king symbolizes a high level of internal development. Also, the kingdom has symbolic dimension, it represents the inner world of spirit and of the soul, the self-control. A king who misuses his power is an evil king.

The male in the story symbolizes the spirit, the mind, and has four stages: boy, youth, adult and old man. Connected with thinking he is exploring the world. The female symbolizes the soul in the stages girl, virgin, woman and old woman. Connected with feeling she turns towards inner life. These steps, in order, correspond to the naivity, then the maturing personality, the mature and experienced one and finally rich characters. Not always are all steps present in the tale. Sometimes there are only two: parent and child. The development of the later is somehow connected to the number of three, the youngest one going the furthest in evolution.

\section{3. "... A Spoonful of Honey"}

A Hungarian proverb says: "With a spoonful of honey can be caught more flies than with a plateog vinegar" ("több legyet lehet fogni mint egy egy kanál mézzel tál ecettel" in original). From this saying the title of this section is derived. The mercy of the undeveloped and therefore weaker hero at the beginning gives him friends who help him to cope with his task.

\subsection{Folk Tales: Grimm: Frau Holle (Germany)}

As an example of a folk tale in which the principle of "... a spoonful of honey" comes to appearances is the German fairy tale "Frau Holle".

Simplified, there can be a division into fairy folk tales and literary fairy tales.

Fairy tales are authored by the people as a collective narrator. The stories are from mouth to mouth, and if necessary modified or supplemented. Traces of the processing of a gifted storyteller can be seen sometimes.

The tale of "Frau Holle" was collected by the Brothers Grimm. Jacob Grimm was born on the 4th of January 1785 in Hanau and died 20th of September 1863 in Berlin. His brother William was born on the 24th of February 1786 in Hanau, and also died in Berlin on the 16th of December 1859. Jacob Grimm was appointed in 1840 as a member of the Academy of Sciences, while Wilhelm Grimm in 1842. During their lifetime they published seven editions of the "Children's and Household Tales" between 1812 and 1857. Their collective work is the most famous German book.

\subsubsection{Brief Summary}

The beautiful, hardworking gold Marie, who has to work hard for her step-mother, loses thereby a coil in a well, take it back and jumps down. There, she finds herself in a fantastic world on a flowery meadow. She takes from the apple tree ripe apples and baked loaves from the oven. Finally, she meets Mrs. Holle, in whose service she enters. Among other things, Mrs. Holle spreads by shaking the snow in the world. For her diligence she is rewarded with the best treatment and care. After some time, she feels homesick and begs to be allowed to return. Entering through the gate into the old world, there are showers of gold. The stepmother sends her own ugly and lazy daughter on the same trip. This does not work. She returns soon. Under the gate, she is showered with pitch, which sticks to her all her life.

\subsubsection{Interpretation}

The tale of Frau Holle shows how the unloved daughter becomes a strong woman. Frau Holle appears here as an initiation master of the woman to maturity through a series of symbolic acts, such as the discovery of the maturity of the bread and apples. The jump in the fountain, symbolising the depth of his soul, self-discovery, is the start of the initiation. The heroines are both called Marie, which has a symbolic meaning: one is gold Marie, Marie, the other pitch Marie, possibilities which exist in every woman. Frau Holle is the goddess of weather, stages of maturity corresponding to the seasons: flowers, ripe fruits, snow. Gold Marie is more developed in the absence of motherly support than her sister for whom the mother acts as a deputy commanding the visit for which she is not mature enough yet.

"Frau Holle" is a fairy tale without men. Frau Holle is the archetype leading to the unfolding of femininity.

\subsection{Literary Fairy Tales: Ion Creangă: "Harap Alb" (Romania)}

As an example of a literary fairy tale in which the principle of "... a spoonful of honey" is expressed, "The White Moor", by the Romanian storyteller Ion Creangă, is analyzed.

The romanticism brought with it the literary fairy tale, as an expression of romantic longing, as a literary genre. Literary fairy tales are much more individual, both in style and in teaching. The fantastic is limited. Also, not so much remained from the folk tale familiar archetypes, but motifs and symbols have been created by the author. 
The structure of literary fairy tale is complex and space, time and social status are portrayed realistically. Sometimes the pursuit of happiness fails. This is something which is rarely the case in the folk tales. For balance in this work tales that are sure an exception were included.

The most famous of the literary fairy tale, Antoine de Saint-Exupery's "The Little Prince", is a work that has been translated after the Bible in most languages in the world.

Ion Creangă is one of the classics of Romanian 19th century. He was born on the 10th of June 1839 in Humuleşti. Close friendship connected him with the Romanian national poet Mihai Eminescu, whom he knew since 1875.Creangă on the other hand, wrote primarily prose. His works include a nearly own genre, not the novel or short story. There are oral narratives that have been brought in written form, the most famous of which is "Amintiri din copilărie" (in English: "Memories from childhood"). Creangă's works are directed mainly at children, but only adults can perceive some subtleties. This also applies to his fairy tales, written 1875-1878, of which "Harap Alb" (in English: "The Tale of the White Moor"), the best known. It is also translated and it been interpreted several times. Ion Creangă died on the 31 st of December 1889.

\subsubsection{Brief Summary}

The Green King asks his brother, to send him the ablest of his nephews to be his successor after his death. The prince, the father of the boys will put this on a dare, which is solved just by the latest, the youngest son. This, advised by the holy Sunday, with whom he has had mercy chooses, takes a miracle horse that disguises itself behind an emaciated appearance, but takes a sample consisting of fire, and embarks on the journey, after he heard the advice of his father. Despite good advice he is betrayed by the Bald Man and becomes its slave. When they arrive at the home of the Green King, the bald man raises before inheriting the nephew and granted unlimited arrogance gives the true nephew the most difficult orders. He orders, one after another, bringing the salads from the garden of the bear, the precious stones from the garden of the deer and the daughter of the red man to him. With the help of various characters, advice on horseback, accompanied by sympathetic monsters, Harap Alb comes well in all situations. At the end the impostor is unmasked and punished, and the hero is rewarded with the blessing of the Green King, the Kingdom and the daughter of the Red King.

\subsubsection{Interpretation}

"Harap Alb" is characterized by numerous elements of a folk tale. Such elements characterize the issue of sovereignty: the starting point of the plot is a king without a successor. The potential successor is found for samples from hard work, courage, power and wisdom and is supported with some samples of grateful animals. The samples, which are set to "Harap Alb" play the role of initiation and are used to select the capable successor. The horse is selected by Harap Alb after a trial. In addition to the grateful animals also semi-fantastic, half-Christian characters play a role (holy Sunday, holy Friday). The Holy Sunday Harap Alb knows differently than his father. The Holy Sunday knows his fate, his essence, while the father was expecting him to be coming back in case of failure.

One must learn everything thoroughly and allow it time, because it must be paid for rashness and indiscretion. Before the trip the father warns Harap Alb for inconsistency, temptations, the evil of the world, everything reduced to the Bald Man and the Red Man. The father had life as a teacher and knows what youth, loneliness and boredom on the long way means. The horse helps, when it can.

Harap Alb is a normal person who cries, laments, is nervous, is suggested by the horse, is a servant, is afraid to have almost fallen in love, and is honest. But he is the reaches the highest, as any fairy tale hero, rewarded for his good heart. He is taking a trip with devoted companions, reminiscent of the search for the Golden Fleece of Jason. The Fellowship of Friends is difficult to separate. During the journey he is becoming a better judge of character and potential rulers, especially after being servant of the Bald Man, who presents him a different kind of samples that are reminiscent of the tasks of Hercules.

The literary fairy tale character is especially noticeable by the presence of elements of peasant life. The elements of peasant life are beyond the pattern of the archetype, giving geographical and historical individuality. So the companions are not imaginary figures, but simply farmers with maximized properties, and the language, especially the names of the characters reveals the location of the action. The fantastic shapes are magical, believable, but not archetypal. Flămînzilă (the man with an unusual appetite), Setilă (the man with an unusual thirst), Ochilă (the man with an unusually sharp eye) have one foot in reality and one in the fantastic world. They are actually farmers with special properties. There is a reference to contemporary life, to the wars and dangers, which can prevent people to come into contact.

Harap Alb he learns to be human, by his own experience, a "sine qua non" condition for the verdict and right 
balance. If anyone knows what suffering is, he will understand the subordinates, one of Christian doctrine transmitted.

\section{The Female}

The representation of the feminine is used in the tales of a more limited repertoire than that of the masculine. The symbols are the mother, daughter and stepmother or witch. Not always the siblings focus on the development of the soul. Thus, the heroines are not three, but often divided into two daughters, not representing the stages of development but very different sisters, as in the history of Frau Holle. Particular importance is attached to the wedding.

\subsection{Strong and WEAK Women: Grimm: The Goose Girl (Germany)}

As an example of the fairy tale about weak women the German Grimm's fairy tale "The Goose Girl" is analyzed.

The Tale of the Goose Girl was collected by Jacob Grimm as "Viehmännin" story, known by Dorothea Viehmann from "Zwehrn" Niederzwehren near Kassel in Germany.

\subsubsection{Brief Summary}

A princess is sent by her widowed mother with precious treasures, a maid, the talking horse Falada and one patch with three drops of blood of the mother on the journey to her bridegroom. The maid refuses to serve the princess and, throughout the journey, replaces her. Upon arrival at the court of the king's son takes as bride the maid, although the beauty of the false maid strikes him. The false bride leaves the talking horse to be killed of fear of his testimony. But the head of the horse, nailed at the city gate, will talk of the grief of the mother. Seeing also his golden hair when looking after the geese the king starts to have doubts and tries to find out the truth. With reference to their silence oath, the two women say nothing, but they are brought to back to their position. Instead of sentence for fraud, the maid is sent in exile.

\subsubsection{Interpretation}

"The Goose Girl" is a tale of the type "The black and white bride", in which not leadership stays in the centre, but a Christian explanation for the disparity between two women are. It is about domination and serving and dependence and independence. Only to be heir to the throne does not ensure leadership, the art of leadership must be learned. Servants must obey, but rulers must be disciplined as well, as a difference to tyranny. To listen to good advice from below, there is reason, not obedience. But this is precisely the fault of the king's daughter. You can not demand obedience from her servant, and in return offer an open ear for suggestions. First, defending the king's daughter did not against the "shameless nature of the chambermaid." Calling God for help, rather than clarify the problems of the maid, with a simultaneous opportunity to comment, what oppresses them, what are their rights but also duties, shows immaturity. No sign of an "open ear" to the bottom, shows inexperience. Immaturity is the condition in which are both heroes and heroines at the beginning of fairy tales, and they must grow out of this to be worthy to take up the leadership - the throne. The samples during the journey are a foretaste of the exam at the court of the king. The golden hair is a kingship symbol. The awareness of wind in their service, as a need for servants, shows the gain of self-consciousness, another symbol of the queen. The gate with the talking horse's head separates the world where the king's daughter is mistress of the geese, of the one in which it serves. While learning about the prospective queen, that servants can rely on the "royal competence," but it is also the task of the good ruler, to provide for their welfare. In other words, take responsibility and enforce for their subordinates, the very picture of today's ideal manager. That was the goal of the learning task, which is also achieved. The same motif of the role of the ruler in his view of modern leadership appears much more explicit in Gosta Berling's Saga.

However, these antagonisms are yet to be seen as stages of development: the transition from one into the next, a learning process. The king's daughter must be the ruling, the lead study. The poor woman is thus a strong one.

\subsubsection{Other Tales}

The brothers Grimm collected many stories about weak women, in Hessen ("Brother and Sister"), for example in the areas of Mainz and Kassel ("The Carnation"), but also in Mecklenburg ("The white and the black bride", a tale of the same type as "The Goose Girl"). But also in Russian folk literature, the weak woman is shown. Gobrecht Barbara presents her collection in fairy tales, the "golden legs to the knee, arms silver to the elbow" in the area south of Arkhangelsk Afanas'ev (- a fairy tale type that is known and loved throughout Europe and even art-tale versions, the most famous of Pushkin: "The Tale of Tsar Saltan, of his son, the famous and powerful warrior prince Gvidon Saltanovic, and their beautiful swan maiden") or elsewhere in Russia ("The Magic Spiegelein", a tale of the type "Snow White" which can also appreciate a literary fairy tale version of Pushkin: 
the verses" The Tale of the Tsar's daughter and the seven dead warriors"), as well as tales from the south of Moscow Aleksandrov-Dol'nik (" The girl with no arms "were a fairy tale of the type "The Girl Without Hands" was collected).

\subsection{STRONG and Weak Women: Afanas'ev, "The Legless and Armless the Warrior" (Russia)}

As a tale of strong women, the collected Afanas'v of Russian fairy tale "The legless and armless warrior of" analyzed.

Afanas'ev has collected tales in this region of Orenburg, at the foot of the southern Urals in Russia.

\subsubsection{Brief Summary}

"The Tsar's son wanted to marry" - so the story begins. His desire bride is a proud, beautiful Tsar's daughter, who has so far rejected all the suitors. He is helped by the bald Ivan, a poor, strong and well-intentioned farmer. The bride put the Tsar's son to three tests of strength. Satisfied with the outcome, the princess marries the prince. On the wedding night the bride discovers that her strength is still greater. Aware of the fraud, she decides to give her husband a lesson. On the way to the kingdom of the tsar's son, they chop off the legs of the bald Ivan and now she is alone with her husband. Bald Ivan Kahle is rescued by Marko. They force a dragon to show them the waters of death and life, and thus his legs and arms grow again. Bald Ivan goes back to see what happened to the Tsar's son. He is freed from the pig-herding-service to which he has been lowered the Czar's daughter, and forced them to accept him as a man. The marriage of the tsar's son is a happy and bald Ivan remains in his service.

\subsubsection{Interpretation}

It is a tale of the type "The strong woman as a bride." The work has similarities to the Nibelungen song, being centrally located in a triangular relationship between a strangely aggressive and powerful Tsar's daughter, which corresponds to the Brunhilde, a soft Tsar's son, the counterpart to King Gunther, and Ivan, the helper, the equivalent of the king's son Siegfried.

The bride is powerful. Her femininity is expressed in beauty and sex appeal. Precisely the strength of the woman wakes in the Czar's son's desire to win her. The bald Ivan, the helper has, unlike the bridegroom, Ivan Tsarevich, power over the bride. In order to preserve their independence, the Tsar's daughter tries to separate her husband from his assistant. Significantly, both male heroes are called the same (like the two Marie). There are two facets of the same ego, two possibilities that lie close together. Unlike in the German fairy tale, it is the hero who is not mature enough to get married to line up next to the leadership of the tsarist daughter. He must first prove that he can carry in his marriage his servant to rule competently.

That the heroine exceptionally strong to tame just a virgin, is an archaic material. And like the story of "Harap Alb" comes out of his drive through the freedom of his helper. If the servant has been rejected as strongly enough, his master is even stronger. However, in a reversal of roles, the Bald Ivan here is the good, and it is also true of the helpers who volunteered to serve, and not to be deprived of legal ruler, as in Harap Alb or The Goose Girl.

The strong heroine is shown from the outside, a display, for the more spiritual symbols, that is male, is suitable for the introspective soul." Especially a new ideal of femininity they represented very convincing. A strong self-consciousness"

\subsubsection{Other Tales}

In the collection of the Brothers Grimm fairy tales are rarely found about the strong woman. Nevertheless, such a tale in Hesse ("The Twelve Huntsmen," a tale of the type "The Abandoned Bride") was found. Remarkable in this is that the woman must disguise themselves as men to be strong. The dress as an expression of the (leadership) personality is a motif that is also in "The Goose Girl", but also in the typologically related story "The black and white bride.

The strong woman as a motif appears much more frequently in Afanas'ev's collection. This collector has such a tale in Arkhangelsk in northern Russia ("The Tale of Tsar brave lads and the Virgin"), in the Orenburg region ("Virgin Czar", a tale of the type "The man in search of his missing wife"), in the southern Urals, and in Kiev ("The animal milk," a tale of the type "The strong woman as a bride", which argue two strong female characters around the hero, his sister and the bride) found, on the Herkunfsort other fairy tales, no data before ("Elena is the very way" related to the Grimm's fairy tale "sea bunnies"). A much more widespread one, the tale of "Mar'ja Morevna," is a hybrid of different types of fairies, which also has a number of Central and Eastern European versions. Grimm's Fairy Tales also include two examples: "The Three Sisters" and "The Princess and the tree", but the heroine in this significantly weaker than the Russian woman. 


\section{Obsession with Power}

\subsection{Folk tale: Grimm, "Sleeping Beauty" (Germany)}

As an example, two German fairy tales are analyzed.

\subsubsection{Brief Summary}

A long time childless royal couple got a beautiful daughter born. At the celebration of this event from the thirteen wise women in the country due to lack of crockery only twelve are invited. At the end of the feast they bestow the girl with qualities. After eleven have made their wonders, the thirteenth came and cursed the girl. It will sting at the age of fifteen years on a spindle and die. The twelfth moderates the curse still, othe daughter will only sleep one hundred years. The King lets all the spindles in his kingdom burn. On her fifteenth birthday, the princess unattended explores her palace and meets an old woman spinning. She takes curiously the spindle, pricks herself on it and falls asleep. Also all the other life events are stopped at the castle. Around the castle is growing around an impenetrable hedge of thorns. From time to time kings' sons bravely attempt to break into the castle, but hang in the hedge and die. After a hundred years the thorns transform in flowers, and the hedge opens up to those who tried it. A king son kisses Sleeping Beauty awake and marries her.

\subsubsection{Interpretation}

"Long ago," begins the tale, meaning mythical time. "The wonderful thing is immanent in the world", as Max Lüthi has said it, here expressed even more clearly than for the room, through the timeline. This approach is taken in fairy tales and legends of the gods in fantasy novels, as Tolkien's, too.

The first emerging theme in the tale of Sleeping Beauty is the first of the heritage of the rule. It is a childless royal couple. Before the birth genetic infertility prevails. Another is the evil power of the female, which appears here in the form of the forgotten god-mother, the witch.

The spindle, which the king's daughter to death and then it will only put in 100 years' sleep, also has a symbolic meaning. The daughter has lost the plot and thus can not lead a life. The date determines when the child progresses to maturity of the personality. The king holds at the time because it burns the spindles. Then the time is stopped during sleep.

The princess finds the spindle, as their parents are absent. The princess has to mature into women and the Goose Girl. In "Harap Alb" it is the king's son. In "Sleeping Beauty" is the daughter is not on a journey, she explores the castle's own home, and thus herself. She recognizes her limitations, and the path leads to the tower. The tower is a symbol of independence. The Russian fairy tale heroines have already achieved this independence. The daughter of the Red King in "Harap Alb" is entirely independent, as it uses the water of life and death to resurrection of the brave and talented, but naive hero. Thus, Arwen and Galadriel, the elven women in the Tolkien trilogy, too. The German fairy tale heroines have the path to independence but most still go through. The first one is before the beginning of the story already." Sleeping Beauty" is active, unlike the unlucky fisherman or Marie. It attacks the stem." The desire for one's own thinking but is under the curse of the Thirteenth." Therefore, the first non-active are rewarded." Wake up in the worldly sense the world is asleep at first but for the spiritual world beyond." To a certain extent, this is the same motif of initiation to maturity from "Frau Holle", a new expression. The expression of an event that happens in the saga of the Nibelungen with Brunnhilde.

Independence is to have its own worldview. To do that, it closes the heroine, even if from an outside influence, in itself is the awakener, when the time is ripe. While he has not understood the process chain, but perhaps its action as a result of pure coincidence on the same basis, appear in the "Frau Holle" no male characters. In her sleep at the time of puberty, the male principle, Sleeping Beauty, and cut off after this time the prince awakens. The hedge of thorns, a symbol of hostility to the suitors, becomes a rose hedge, a symbol of love.

"The idea of a female figure, which is sunk into a magical sleep and reappears after some time", is, according to Marie-Louise von Franz archaic material, as well as the Russian fairy tale.", the Virgin awaiting to awake. Bridegroom is a Christian symbol. Salvation begins without personal merit, by grace. The hedge of thorns symbolizes a power complex: the tyranny. Patience and passivity have success over aggressiveness. Time plays a crucial role.

\subsubsection{Translation into Architectural Landscape}

Outgoing from the story of the Sleeping beauty, we designed the garden of the Paradise.

Designing gardens is like telling stories, just that stories have an end, and gardens are never ended.

As the sleep of the princess was no death, maybe the garden of the Paradise is not lost without return either, but 
only slept in in each of us and waits to awake. Since leaving the Paradise gardens were expression of the images about something not to be missed but lost.

Hundred years the garden remains inaccessible. To the time of the Renaissance the motive of initiation gardens was introduced. The labyrinth garden represents our world rich in information and networked. The man remains despite his numerous contacts more and more alone in his interior world; for each one remains an individual reality which cannot be connected into this network.

And in the deepest is the garden of the Paradise. In the garden of the Paradise there are other laws, because it is in another world, the interior world of people. Nobody can represent it, but the art can bring it up, to the extent to which it reaches self consciousness.

But after 100 years the garden opens.

Limits mark our world. For the Paradise is still valid, on the contrary, the unending. The Paradise can be reached only uncoupling some dimensions, and out of these the one of the time is the first.

As an eye in the lace of life, the moment is in no case something isolated, but contours the gate to what is behind life. Life, consisting of independent eyes, becomes a row of gates which lead to parallel corridors, which lead so to others. A certain moment becomes for us an unexpected gate, which leads to the mystical.

The lace of life, made out of separated eyes, disappears in the moment when we find the gate to what has glittered before behind life. We are headed to what is behind the world but without leaving this world.

We step on a glass surface, transparent and mate, and from below the eternal fall follows us.

The interior world is what can be found for us behind life, the virtual. This can be accessed only through senses. These constitute the unexpected gates.

And finally the thorns transform in roses. In each man there are two polarities, and one of them is the need of unending. The other is the satisfaction with the earthy life. The story ends. Nobody can live in the Paradise again, as something has been witched again. The actual Paradise, the eternal deepnes, finds itself through this, which we reach through the world of senses and finally in the excitation of the external world. Coming back is as important as entering, as men can perceive the lost world only based on the contrast.

Based on this concept a garden of Paradise was designed, consisting of a roses hedge, in which various spaces are cut, in a labyrinth like succession, leading to a meditation space. The spaces correspond to the elements, sentiments, seasons and the moments of life, as they are expressed in the Chinese mytology.

So, the centre corresponds to the Earth, the thinking, mid sommer, yellow. Around it are:

- The white tiger: the west, the autumn, sadness, metal, evening;

- The black tortilla: the north, the winter, fear, water, midnight;

- The blue dragon: the east, the spring, fury, wood, morning;

- The red bird: the south, summer, happiness, fire, midday.

Under the image of the four mytical animals there is a Chinese system of inductive correlations. Although we recognized the Ying-Yang intercalation, the world is not seen as interdependence of contradictory pairs, but as evolving fenomenon in five phases.

In this system of five phases the interior and the exterior, the interior world and the exterior one are next to each other, because in the Chinese mythology they are not separated. There are transcendental links between the interior and the exterior world.

For the space of beauty we chose elements to express liberty, movement and rhytmus, atmosphere, leaving the intellect, beautiful music, radiosity, light. There is a fireworks play in this space.

For the space of meditation we left the scale, and chose isolation, intimity, difuse light, silence, and an uncontured shape. This space is a stone garden, in Japanese style.

For the space of sadness we chose simplity, running lines, a beautiful light, multiply reflected, white, grey, green and blue, a strong orizontality. These spaces are consisting of stepped terraces.

For the space of fear we chose a narrow space, lacking landmarks, closed, tensioned, without stability, noisy, vertically illuminated, a surprising appearance. This space is a cascade which encompasses all the circular area.

For the space of dynamics we chose oblique lines, strong materials, verticality, an accentuated direction, red, blue and yellow. This space is a tunel in the shape of a flash light. 
The labyrinth parcours is in the following succession: sadness (access), fear, dynamics, happiness, meditation, after which the cycle repeats. They have been ordered following the cardinal points in mythology.

\subsection{Folk tale: Grimm: "The Fisherman and Syner Fru" (Germany)}

The fairy tale "The Fisherman and his Wife" was collected by the Brothers Grimm in northern Germany.

\subsubsection{Brief Summary}

A fisherman, who lives with his wife in an old pot catches in the clear water a talking fish that is an enchanted prince. He lets him free again. When telling about this to his wife, she asks him to call back the fish and ask in return for a hut. The fisherman goes reluctantly to the sea, which is now green. The fish he willingly granted the request. Returning home, he meets the happy Ilsebill. After two weeks the woman is no longer satisfied and persuaded him to ask the fish for a castle. The water is now thick and purple, the fish willingly again. Home the fisherman finds a magnificent castle with servants. The wife calls him the next morning to be king over the land. The fish is now in putrid gray water. The fisherman admires his wife, who now sits in a luxurious palace with a huge entourage and army. After a short time the woman requires to become emperor. The fish in the dark, frothy simmering water listens again. Immediately after his return, the wife sends him again to the fish again, as she wants to be pope. In the sea there are now many ships in distress, the fish listens again. Surrounded by countless palaces with submissive rulers Ilsebill, the wife, wants next morning to be God to govern the sun and moon. After her husband brings this request before the fish amidst towering waves, she is sitting back in the old pot.

\subsubsection{Interpretation}

The theme of power is very clear in the tale of the fisherman and his wife. It is the unbridled lust for power, which grows here in four steps. First, the desire is enjoyed, but then disrupted by the difference between between desire and reality. Gradually decreasing is enjoying the fulfillment of the desire. The greed is represented psychologically correct, by shrinking the time intervals between requests. The new request is delegated from the woman to the man and from man to fish. The last stage is the idea of loss.

Ilsebill behaves like a ruler, though not as one of the good. The higher it is on the dignities ladder, the more dominant she behaves towards her husband. She orders him and used the fact that for the fulfillment of their wishes does nothing else than to delegate it to her husband. The mood of the fisherman, as the weather, is always sorrowful, but he acts from outside, saying that it is wrong to ask the fish for more, with no decisive action from within her character changes. Instead, he complains to the fish over the lack of understanding of his wife and talks to himself, he lacks courage. In a sense it is a similar situation as in "The legless and armless the warrior", where the man can not carry in his marriage. Unlike there, however, the woman is incapable of leadership here. She wants a leadership position, but because they cannot do anything with the skills belonging to it, she is not satisfied and thinks a higher authority could bring her fulfillment. His wife opposes in both cases the husband desperately.

"The fisherman is afraid of a punitive authority." After Verena Kast a possible explanation of his inaction, the hope is on its power. The delegation of power prevents him from his bad feelings to behave accordingly.

In this fairy tale requests are within the meaning of "wanted" power which is symbolized by "having".

\subsection{Fairy Tale Novels: Michael Ende: "The Neverending Story" (Germany)}

Rein A. Zondergeld and Holger E. Wiedenmann tried in "Encyclopedia of fantastic literature," a definition of the literary genre of the so-called "Fantasy". They cited the French theorist Roger Caillois: "In the fantasy the supernatural reveals as a crack in the universal context." The spectrum of the genre, called the "fantastic literature", is immense and covers of classics of world literature such as Honoré de Balzac, on A.E. Poe to contemporary horror writers like Stephen King. Fantasy-stations are located along the border between fairy tales and science fiction literature. In this work exemplary insight is given into the most famous work of today's most famous fantasy author.

On the border of science fiction and fantasy is also the most famous work by Michael Ende, "The Neverending Story".

Gods and heroes of the past continually fascinate people of all ages. Besides well-known legends of the Greeks, Germans ("The Nibelungen") and Celtic ("King Arthur"), the genre was again enriched by "Art Share". The Saga of Gösta Berling, written by Selma Lagerlöf bears this title worthy addition, there are woven into her Swedish fairy tale worlds. It is different from John's Glasworthy Forsythe Saga.

In summary, we have this section of the work "fairytale novels", such as Michael Ende his work "Momo", perhaps a much better label for this genre. 
Michael Ende is one of the most famous German writers. He was born in 1929 in Garmisch-Partenkirchen and died in August 1995 in Stuttgart. Michael Ende was a versatile author, through the "fairy-tale novels," picture-book texts, plays and poems has written. Many of his works were filmed, but the most famous of these is "The Neverending Story". With the "Neverending Story" and "Momo.A fairy-tale novel, " he has not only re-opened fantasies for both children and adults, but also gained world fame.

\subsubsection{Brief Summary}

The "Neverending Story" also includes two stories: the story of Bastian and the history of fantasy. The transition between these two worlds is marked in the book with color: the real world, in which Bastian is living is described in red, the happenings in Wonderland fantasies in green. The importance of writing is addressed at the beginning of the tale: the inscription of a shop seen through a glass pane and vice versa. Bastian is a 11-year-old boy who is teased by his classmates because of both its thickness and poor academic performance and exclusion, but also by his father who since the death of his mother does not care more. Bastian finds refuge in fairy tales. Bastian could do best: even invented stories are clearly present at your fingertips.

One day, Bastian steals a book from a bookseller, which exerts a tremendous attraction to him, and flees to the deposit of the school building. The title of the book reads: "The Neverending Story". "It will be clear later that the theft of the book was already one of Bastian's fantasies."

The country is threatened with destruction fantasies. Atreju, the destined hero in the tale, in fact, a boy, manages not to rescue fantasies. Everything he achieved after many adventures, is the key to solving his problem. A man, a being that lives on beyond imagination, must give the Childlike Empress, the ruler of this country, a new name. Bastian knows himself appointed for this task. Bastian spontaneously calls the Empress "Moon Child". He saves fantasies and gets the reward of every fairy tale heroes: the rule. But that's not the end of the story. While Bastian threatened them, falling into the slavery of his own power, the power that all wishes come true, Atreju, the fairy tale hero, helps him in reality, back into the real world. The reward is Bastian's self-knowledge and self-acceptance. First, this is expressed through the love of his father, but the love is a deeper meaning to itself. Bastian is self-conscious, and his father rediscovered.

\subsubsection{Interpretation}

It is already in the red-green split to recognize that the one-dimensionality is exceeded by fairy tales. This hand is red, green afterlife is like the skin's color of Atreju. It also requires the imagination of the sovereign individuality to live on. The transition from reality to fantasy is psychologically represented by smaller and smaller distances, as the increase in demand rush in "The Fisherman un syner Fru". Again, it's about to be desired. Incoming travelers for fantasies get the Auryn, a medallion with the Inschift "Do what thou want." Font and name and have a special meaning. Auryn, with its inscription symbolizes unlimited power. The power that all wishes come true immediately, also acts as a noise on Bastian, unlike the fantastic creatures from beyond. Unlike the fishermen Bastian has a boyfriend. Also unlike the fishermen Bastian overcomes his inhibition and has the courage to give the Empress a name. It should be recalled here that the sad fate of the fisherman and the "inhibited aggression, lack of courage to call a spade a situation, the lack of decisive action in a situation" is assigned. The path of the hero this time is reversed, it is conjured in fantasy, and the writing is green everywhere. And as in every fairy tale the companion of the hero helps Bastian to develop himself. The rule derived from Bastian is expressed by absolute power. And she and Mr. Bastian of Bastian is not about them. Under the rule of power Bastian begins to forget what he is. But this would mean the end of any power, because the memories are the ones which dictate his wishes. It is understood that full power is not unlimited freedom, it is to be equated, and that the barriers will come from the inner need. Freedom does not mean to do what he likes, but to do what he really wants. Even if only a magical fantasy land is injected into the reality of the way Bastian brought about by fantasies like any fairy tale hero positive changes. There is no jump in the fountain, there is a "leap" into fantasies, but this has the same effect: the initiation and self-knowledge of the hero. The unconscious is integrated into consciousness.

"Such a process, as it has gone through by Bastian, calls the depth psychology of individuation." "A larger, more mature personality is visible and tangible for others ... The emotional center is organized by the growth of this seems a kind of "nuclear atom" to be the soul. [...] Jung called this center as the self. It represents the totality of our psyche is, in contrast to the ego that is only a small part of our mental life area".

These views of depth psychology according to Gronemann have been known since long in religion. The principle is: the "hero" is evolving towards a draft. Given the scope of the work in this paper only some relevant aspects are discussed in detail. One such aspect is that people are more susceptible to power than other beings: 
"It is up to Auryn ... ... The gloss looks at our one, unlike a human child ... The characters are your great power, are you fulfilled all your desires, but at the same time it takes you a bit: the memory of your world."

Another place where the issue of self-control is treated is the magical part of the three gates. In whose image Bastian is shown how the path should look to the self. It takes courage to not be overwhelmed by the fullness of being. This is the way through the first gate. One must deal with a shadow, with its hidden, often weird appearing properties. This is the way through the second gate. One can not hold a rash of unconscious possibilities for the self, for the true will, rather it is necessary to constantly keep in view the huge range of possibilities and wishes of its intent, the self, seeking the divine spark. This is the way through the third and last goal.

\subsubsection{Translation into a Scenographic Installation}

We also designed a spatial scenography for the doors in the Neverending Story, which can be well translated into computer simulation, in an immersion discovering the feeling of the spaces, sketching them in a simplified manner. A first sketch is the 2-dimensional representation of the photograph. Then another kind of door can be conceived, to enter the heritage space:

1. In a first stage there is the shadow. In the rediscovered space we saw only shadows. The shadow left by light through the glass of the door on the wall, or the complex shadow left by spaces in the box.

2. In a second stage there is a mirror. The photographs come close to the mirror. They reflect.

3. In a third stage there is a projection. The projection incorporates what today's architecture practice has to add to the interpretation of the $20^{\text {th }}$ century architectural heritage, what and how has to be preserved. An excellent example was given by the architecture of Carlo Scarpa the historic substance being layered with contemporary interventions.

\subsection{Fairy Tale Novels: J.R.R. Tolkien: "The Lord of the Rings" Fantasy (England)}

John Ronald Reuel Tolkien was born on 3 January 1892 in Bloemfontein / South Africa. In 1896 he came to England. Tolkien was a professor of Germanic philology at Oxford. He died on 2 September 1973 in Bournemouth. The trilogy "The Lord of the Rings" is his most famous work, which is regarded as the most important fantasy work and contributed much to the genre that has become known, particularly since the Oscar-award-winning film adaptation. It supports the success of this genre through the relationship and transferability to adventure and role playing, sometimes on computer games, which at today's generation of young people, and not only these, are very popular.

\subsubsection{Brief Summary}

The hobbits, a little-known species of beings are in possession of a wonderful ring. This ring was created in primeval times by Sauron, the "Dark Lord" of Mordor, in a volcano, Mount Doom. Although the ring has escaped from the property of its creator, he has kept all its properties, even more, they begin to wake up after a long sleep. The ring has its own will and seeks Sauron, for which the ring is a tool for power procurement. Many have already felt in the power of Sauron, when he offered this power. To prevent the shadow of power it to spread over the rest of Middle-earth, including the Shire, the ring must be destroyed precisely at the place of its creation. The long journey to the land of evil is done at the beginning of the companions, representatives of all the magical creatures of Middle Earth. But at the entrance to the land of Sauron, Mordor, the Ring-bearer Frodo is alone with his friend and servant, Sam. Sam helps him to perform his duty to a good end, even though the "hero" is not always stronger this time, but by the physical proximity of the ring always attenuates his strength. At the end he leaves Middle Earth for a better world, as some have to give up the things for which they fought, so that others may keep them.

\subsubsection{Interpretation}

History should be a true story of old times, where elves still have lived together with people on this earth. The book, where everything was recorded, has disappeared, however, serve copies, songs, poems and diary of two hobbits as sources for the "historic copy of the history of the War of the Ring". This makes "The Lord of the Rings" more the type of "announcement" due and relies more on memories of old times, as to archetypes. There should be no fairy tale romance, but the novel fused "art legends."

"The Lord of the Rings", like any fairy tale, even if there is a "fantasy"-factory, is on the struggle of good against evil. The evil is symbolized by the "dark", you could say "bad", Lord Sauron. The ruler of darkness is due to his addiction to power, because Sauron gives the power to dominate the rest of Middle-earth. The aim is to lead and not to dominate.

The structures of power as rulers and masters are set up similarly to the "Neverending Story". Although the 
hobbits have the physical entity of the ring, the nature of the ring escapes them completely. The aim is to have power only because slavery begins in the service of power. The ring may not be used because its use would only involve themselves in hierarchies of power.

It is "The Work", which addressed the issue of sovereignty centrally. The following are some excerpts are quoted:

"And suddenly he felt the Eye. There was an eye in the Dark Tower that did not sleep. He knew that it had become aware of his gaze.

He heard himself crying out: Never, never! Or was it: Verily I come, I come to you? He could not tell. Then as a flash from some other point of power there came to his mind another thought: Take it off! Take it off! Fool, take it off! Take off the ring!

The two powers strove in him for a moment. Perfectly balanced between their piercing points, he writhed, tormented. Suddenly he was aware of himself again. Frodo, neither the Voice nor the Eye: free to choose, and with one remaining instant \# in which to do so. "

"Indeed in nothing is the power of the Dark Lord more clearly shown than in the estrangement that divides all those who oppose him quiet."

"In place of the Dark Lord you will not set up a Queen. And I shall be dark, but beautiful and terrible as the Morning and the Night! Fair as the Sea and the Sun and the Snow upon the Mountain! Dreadful as the Storm and the Lightning!

Stronger than the foundations of the earth. All shall love me and despair!"

She lifted up her hand and from the ring that she wore there issued a great light that illuminated her alone and left all else dark. She stood before Frodo seeming now tall beyond measurement and beautiful beyond enduring, terrible and worshipful. Then she let her hand fall, and the light faded, and suddenly she laughed again, and lo! She was shrunken: a slender elf-woman, clad in simple white, whose gentle voice was soft and sad. "I pass the test," she said." I will diminish, and go into the West and remain Galadriel."

"I wish you'd take his ring.'d Stop them digging up the gaffer and turning him. Adrift You'd make some folk pay their dirty work."

"I would," she said." That's how it would begin. But it would not stop with that, alas! We will not speak more of it. Let us go!"

He Seemed to have grown in stature while Jomer had shrunk, and his living face they caught a brief vision of the power and majesty of the kings of stone.

\subsection{Fairy Tale Novels: Selma Lagerlöf: Gösta Berling's Saga (Sweden)}

Selma Lagerlöf was born on 20 November 1858 in Varmland, Sweden. "Gösta Berling" was her first novel, but also her breakthrough. She received the 1909 Nobel Prize for Literature, and in 1914 she became the first woman in the Swedish Academy. She died on 16 March, 1940.

"This was the Baroness. She went quietly, but there was horror in its wake. She fell, but even humiliated she was not without greatness. She gave herself no effeminate pain, but rejoiced at the age of their young love. You humbled neither complaints nor effeminate tears as she left everything, and they did not hesitate to go with the beggar's bag and walking stick through the country you only regret was the poor peasants and the happy, carefree people on the banks of the Lofven, and the poor cavaliers: all those who protect and support had been.

Of all she was leaving, and yet they still had power to expel her last boyfriend in front of him, so he was not a murderer."

\subsubsection{Brief Summary}

Gösta Berling is one, because of his drunkenness, defrocked minister. However, he had the inspiration of the moment and passed the test, if not the fate of one of his friends would have robbed him temporarily of reason, so he tried to scare the inspectors. Then Gösta voluntarily left his parish and tried to commit suicide. It is rescued from the snow by the major's wife, who is the model of the ruler in this novel. When at the Baroness, he could combine with other cavaliers a totally carefree life, but the devil gets involved and makes a pact with the Cavaliers, that occurred one year after her fall and may administer the estates of the Baroness. The Baroness herself becomes a beggar. The entire novel describes this one year and takes up relating to the beautiful Swedish nature in all seasons and times of day. People's lives grueling runs, accompanied by love, death and disease that leave lifelong mark. Gosta, the main character, falls himself three times, but the first time, his love is superficial 
and is caused only by the appropriate atmosphere. Only the third beloved, the Countess Elizabeth, an already married woman turns out to be his true love, because he loves her at first her soul and sees only her beauty, a fitting cover for it. At the same time experiencencing a tragic marriage, the Countess story that seems to have removed the least of our times.

\subsubsection{Interpretation}

Now that Phantasy novels have become with the success of the film version of Tolkien's masterpiece so popular, I have seen this novel with many interwoven tales through different eyes. There are fantastic figures in Gosta Berling's Saga. The devil, the old woman, and the witch of Dovre appear in one or the other. But they appear in the same way as in any other literary fairy tale: to help the hero to develop himself, and are also credible. The emphasis is on the hero, and he is a normal person without supernatural abilities.

The hero himself, Gösta Berling, is full of charm. He not only won more characters in the novel to his side, but the readers themselves with full "sins" and still with a good heart, who may not recognize themselves in Gösta Berling?

Gösta Berling occurs at the site over the love of his life story: Elizabeth. Most purely positive characters in novels are less successful, and so suffers also Elizabeth. While almost all women are beautiful in the novel, some more, some less, the emphasis to Elizabeth on her good heart. Elizabeth is also beautiful, but her character exudes quality. However, they will give us better by the reactions of others as by their actions and especially their own thoughts, because they do not seem particularly unusual. Actually Gösta Berling is in his best moments, not far away from her, and I was wondering whether the real reason that he himself has not proposed to marry her, but she always wanted to serve, it is that he has good moments and bad moments, had wanted to appear in front of her face but only in his bad moments.

A much more exciting aspect of those of good heart: the attractiveness and the influence that this exerts on the people. The common people and even some of the nobles are respecting the goodness. You feel relieved and see the beautiful life, simply by the recognition that goodness exists. This is something that should give the current widespread egotism to think, and the moral is conveyed wonderfully. Relatively frequently occur in the novel the terms "rule" and "rule" before. It is important to distinguish between ruling: the wise rule and tyranny. And this is the one that is taken as an example. I personally found it a fairly modern phenomenon for this time, that the landowners have not exploited the population so they can live in a rich doing nothing, but her honor and virtue was to manage the assets and thus as many ordinary people were offered a job (which is addressed almost by these terms).

\section{Conclusions}

In addition to the deeper meanings found in fairy tales catching case studies give lessons about leadership issues. Some examples:

- $\quad$ Sleeping Beauty: A disgruntled employee (the 13th witch) affects the whole operation process, many good forces (the other twelve) can not save much. An undisclosed threat to job security (the spindle in the tower) is addressed promptly, to damage, if it is accidentally discovered, the employee would have been informed, they could avoid them. Fame and reward (marriage) to the fall, which makes an opportune chance (after 100 years), not their own power will prevail.

- The Goose Girl: The inexperienced manager (princess) is rude to the staff (maid) and to its authority from the backing of a senior management concerns (blood drops of the mother) and therefore loses it soon. She brings herself at a disadvantage by devious rules strictly followed (forced oath). On her new job she is sexually harassed (hair). She retaliates by bullying and delegated this task (the wind). The open protest of the disgruntled employee (Conrad) adjusted finally the whole situation and also helps the accused. When people talk convened dares to subordinates any statement (servant to the king), the critical information flow channels in the dark at management level (stovepipe), the leadership can encourage this deliberately.

- Mother Holle: At exactly the same tasks, the quality of the work entirely on the motivation of the employee.

The heroes or heroines of folk tales are simple people who have distinguished themselves at the end by virtue and reason. You never have an individual personality, but represent archetypes of the order of life. The heroes in the Russian fairy tale, for example, all Ivan-Tsarevich, and also in the German fairy tales rarely have a name. In contrast, the heroines are usually individualized. They carry out their duties not alone, but together with helpful assistants and animals on their side. Male heroes go through a test as a result of the unstable character at the beginning. Their spiritual development corresponds to the initial stage of the boy. Only after the character samples, actually the biggest task of the hero, they become "real" heroes. But all are characterized by 
compassion and humility, and thereby create supportive helper. By modesty, which stimulates the generosity of the helpers, the hero reaches the highest. There are the volunteers who have the ability to complete the task, as wisdom, courage, endurance, strength, appetite and great thirst. At the end of the story there is the reward of the good - a leadership position: Kingdom of the successor or by marriage with a princess - and the punishment of evil - death, the goal of the career. The hero takes on the characteristics of his aides and his opponents in superating the "final exam". After the test of character, where more self-control is needed, the confrontation with the evil is a sample of the ruler. The hero reaches the highest position which is shown as morally "throne for the humble," a reversal of the original situation. Punishment and reward will be intensified in order to establish this as a "moment of finality."

Leadership means always, to deal with his own personality. First comes the "self-mastery," then the "rule". It serves this purpose the tale of initiation. Not only male characters can be initiated, according to the samples to be done by heroes, just as in the history of "Harap Alb". In the work presented in this tale, it is mainly the female characters who are going through an initiation, in the tales of "Frau Holle" and "The Goose Girl", and even to some extent in "Sleeping Beauty". But also extensive literature works, such as Michael Ende's "Neverending Story" are dedicated to the initiation as a main theme. Female characters appear also in "Neverending story" (the empress to get a name), in "Lord of the rings" (the test of Galadriel) and in Gösta Berling (the real rulerin the Baroness).

In fairy tales, we find two different leadership styles. Authoritative leadership is in the form of tyranny both in the folk tale "Sleeping Beauty", but more complex than power expressed as a power of obsession, as well as in Tolkien's novel "The Lord Of The Rings" because of the dispute. Cooperative management on the other hand seems to be a theme that characterizes rather the literary landscape of literary fairy tales. Is guided through the winning of companions in "Harap Alb" and "The Lord Of The Rings".

Of the management tools mostly used is that of the delegation. This is the case in the fairytale "The Fisherman and syner Fru" and the fantasy novel "The Lord Of The Rings".

As properties of the good "bosses" in particular praised are the decision and the fair treatment and less the organizational skills. Thus, the lack of self-initiative in "Frau Holle" was punished as an inability to make decisions, whereas in "Sleeping Beauty" it was allowed when it comes to dealing with tyranny. Closely related is the lack of independence. "Service", the antonym of gentleman's words, means to be dependent and therefore make no use of the power of decision. This is the case in "Goose Girl" and "The Lord of the Rings". Organizational skill has a go only in the saga of "Gösta Berling," where the ruler's leadership role is justified through the creation of jobs, an organizational role.

A delicate balance must be drawn between "strength" and "power" as the two poles of the leader. While the strength of the monarch in "The legless and armless warrior" tends to be quite positive, impressive property is shown, the consciousness of power to make greedy, as in the fairy tale "The Fisherman and synergistic Fau," in the "Neverending Story," and in the novel "The Lord of the Rings."

\section{Acknowledgements}

This work was completed as assignement about personell management in the project management certificate work by the authors at the University of Karlsruhe. The Paradise Garden has been designed under the guidance of the late Dieter Kienast at the University of Karlsruhe. The paper has been translated and updated in frame of the COST action genderSTE.

\section{References}

Creangă, I. (1956). Märchen. Berlin: Aufbau-Verl.

Ende, M. (1997). Die unendliche Geschichte. Stuttgart: Thienemann.

von Franz, M. L. (1997). Das Weibliche im Märchen. Leinfelden-Echterdingen: Bonz.

Gobrecht, B. (1996). Märchenfrauen: von starken und von schwachen Frauen im Märchen. Freiburg im Breisgau; Basel; Wien: Herder.

Grimm, J., \& Grimm, W. (1975). Kinder- und Hausmärchen. Stuttgart: Parkland-Verlag.

Gronemann, H. (1985). Phantasien - das Reich des Unbewußten: "Die unendliche Geschichte" von Michael Ende aus der Sicht der Tiefenpsychologie. Zürich: Schweizer Spiegel-Verl.

Jung, C. G. (1968). Der Mensch und seine Symbole. Freiburg i. Br.: Walter-Verl.

Lagerlöf, S. (2001). Gösta Berling. München: DTV. 
Lenz, F. (1997). Bildsprache der Märchen. Stuttgart: Urachhaus.

Lüthi, M. (1990). Märchen. Stuttgart : Metzler.

Kast, V. (1988). Mann und Frau im Märchen. Olten; Freiburg im Breisgau: Walter.

Riedel, I. (2001). Wie aus der ungeliebten Tochter eine starke Frau wird : Frau Holle. Stuttgart: Kreuz.

Tolkien, J. R. R. (1995). The Lord of the Rings. Harper Collins.

Zondergeld, R. A. (1983). Lexikon der phantastischen Literatur. Frankfurtam M.: Suhrkamp.

\section{Copyrights}

Copyright for this article is retained by the author(s), with first publication rights granted to the journal.

This is an open-access article distributed under the terms and conditions of the Creative Commons Attribution license (http://creativecommons.org/licenses/by/3.0/). 